\title{
The Effect of Sr Modifier Additions on Double Oxide Film Defects in 2L99 Alloy Castings
}

\author{
QI CHEN and W.D. GRIFFITHS \\ In this paper, Sr modifier (300 ppm) was added to $2 \mathrm{~L} 99$ alloy sand castings to investigate its \\ effect on bifilm defects in the castings. Two different sand molds were used in this study, with \\ good and bad running system designs, to introduce different amounts of bifilm defects into the \\ castings. The mechanical properties of the modified 2L99 castings were compared to the \\ properties of unmodified castings and showed that with high bifilm defect contents $(\mathrm{H})$ the $\mathrm{Sr}$ \\ addition reduced the Weibull modulus of the UTS by 67 pct and the Position Parameter by \\ 5 pct, and introduced a bimodal distribution into the Weibull plot of the pct Elongation. \\ However, for castings with low bifilm defect content (L), the Weibull moduli of both the UTS \\ and pct Elongation were significantly improved (by 78 and 73 pct, respectively) with the \\ addition of Sr. The Position Parameter of the pct Elongation was improved by 135 pct. The \\ results suggested that a desirable modification effect can only be achieved while the bifilm defect \\ content in a casting was low.
}

DOI: $10.1007 / \mathrm{s} 11661-017-4310-8$

(C) The Author(s) 2017. This article is an open access publication

\section{INTRODUCTION}

AL-SI alloys are widely used in the automotive and aerospace industries due to their high strength-to-weight ratio and castability. However, the plate-like coarse Si phase is usually accused of reducing mechanical properties of the alloy. To solve this problem, minor chemical modifications are used to modify the plate-like Si morphology into a fibrous or coral-like morphology so that mechanical properties, especially ductility, are improved.

Various elements are reported to have a modification effect on $\mathrm{Si}$, among which $\mathrm{Sr}$ and $\mathrm{Na}$ are the most commonly used.$^{[1-3]} \mathrm{Ba}$ and $\mathrm{Ca}^{[4,5]}$ are also reported to have a similar but reduced effect on Si. Of the commonly used modifiers, $\mathrm{Sr}$ remains longer in the melt than $\mathrm{Na}$ but is well known for its association with enhanced gas porosity ${ }^{[6]} \mathrm{McDonald}$ et al. ${ }^{[7]}$ investigated porosity in a Sr-treated alloy and found that, at any $\mathrm{Si}$ content, porosity was increased when $\mathrm{Sr}$ was added. Tiedje et al. ${ }^{[8]}$ suggested that $\mathrm{Sr}$ modification would increase the amount of porosity by 5 to 10 times in an $\mathrm{Al}-\mathrm{Si}$ alloy.

The impurity-induced twinning (IIT) $\operatorname{model}^{[9]}$ and twin plane re-entrant edge (TPRE) mechanism ${ }^{[10]}$ are

QI CHEN and W.D. GRIFFITHS are with the School of Metallurgy and Materials, College of Engineering and Physical Sciences, University of Birmingham, Edgbaston, Birmingham B15 2TT, UK. Contact e-mail: Q.Chen9927@gmail.com

Manuscript submitted April 23, 2017.

Article published online September 14, 2017 accepted as explaining the modification behavior. Modifier atoms, with a ratio to $\mathrm{Si}$ of $r$ (modifier): $r$ (silicon) $=1.646$, are selectively absorbed at re-entrant edges, deactivating the preferential Si growth directions. Another explanation would be that the modifier atoms are absorbed at the growth steps of Si crystals, interrupting the current growth of the Si phase. The Si atom was forced to fall into the next available vacancy and its stacking sequence was changed. The formation of twins of the Si phase was also increased. Li et al. ${ }^{[11]}$ observed the absorption of $\mathrm{Eu}$ atoms (with $r$ (modifier): $r$ ( $\mathrm{Si}$ ) roughly equal to 1.646) at twin plane re-entrant edges using STEM. Timpel et al. ${ }^{[12]}$ used atom probe tomography and TEM with nanometer resolution to investigate the behavior of $\mathrm{Sr}$ in $\mathrm{Al}-\mathrm{Si}$ alloy and suggested that the segregation of $\mathrm{Sr}$ is responsible for the formation of multiple twins restricting the $\mathrm{Si}$ growth. Sr modification was successfully simulated by Eiken et al. ${ }^{[13]}$ using 3D phase field simulation, based on the above two mechanisms.

The topic of bifilm defects was raised by Campbell in the 1990s and since then has led to more awareness of liquid metal quality in the casting of light alloys. ${ }^{[14]}$

Liquid aluminum will readily form a very thin layer of oxide on the surface of the melt. During the process of liquid metal transfer, the surface of the liquid metal may experience some turbulence. If the local velocity of the liquid metal exceeds about $0.5 \mathrm{~ms}^{-1},{ }^{[14]}$ the liquid metal can fold over onto it trapping a pocket of gas. This "doubled-over" structure can then be entrained into the bulk melt and carried around by the bulk liquid flow. 
Once solidified, it forms a defect leading to both a reduction and a variation in mechanical properties.

In order to quantify the effect of bifilm defects, mechanical test data from castings are usually fitted into a Weibull distribution. This was proposed by Weibull in 1951. ${ }^{[15]}$ Campbell and Green ${ }^{[16]}$ used a two-parameter Weibull distribution to describe the properties of Al-7Si-0.35 Mg alloy and suggested that the use of a Weibull distribution produced a better data fit compared to a normal distribution. Tiryakioğlu et al. ${ }^{[17]}$ further improved the estimation procedure for the Weibull parameters, with the help of Monte-Carlo simulation, so that the distribution can better represent the mechanical properties of the casting.

Nyahumwa $^{[18]}$ proposed a hypothesis that the entrapped atmosphere in a bifilm defect might be consumed gradually, with initially oxygen and then nitrogen being consumed, and when the majority of the entrapped atmosphere was depleted, the unwetted sides of the bifilm defects might close and bond together, reducing the detrimental effect of bifilm defects.

It has been suggested that the addition of modifiers might change the oxidation behavior of liquid Al-Si alloys. ${ }^{[19-21]}$ A Sr-related oxide might be formed in Al-Si alloy as observed by Jacob et al., ${ }^{[21]}$ which are thick (as thick as $500 \mathrm{~nm}$ ) and non-uniform in thickness. Emadi et al. ${ }^{[20]}$ suggested that the oxidation rate was accordingly increased by three times when $\mathrm{Sr}$ was added into an Al-Si alloy. The changed oxidation behavior of liquid aluminum alloy might then alter the behavior of the oxide skin and hence the consumption of the entrapped atmosphere within a bifilm defect which, in turn, might affect the mechanical properties of the casting.

The behavior of bifilm defects in the casting might be affected in a Sr-modified casting. ${ }^{[22]}$ Reiszadeh et al. ${ }^{[23]}$ suggested that the addition of $\mathrm{Sr}$ reduced the rate of consumption of the air trapped in a bubble held in the melt and would have the same effect in a bifilm defect. Nateghian $^{[24]}$ suggested that, with the addition of 0.05 wt pet $\mathrm{Sr}$ to commercial purity aluminum, the $\mathrm{Al}_{2} \mathrm{O}_{3}$ layer started to transform into $\mathrm{SrO}$. Farhoodi et al. ${ }^{[25]}$ suggested that such a transformation might make a bifilm defect stronger which would produce less rupture points and thus the entrapped atmosphere was less likely to be consumed. In this case, a bifilm defect should last longer in an aluminum melt containing $\mathrm{Sr}$ (and contribute to increased porosity in the aluminum castings). However, no evidence supporting such a hypothesis was provided.

Another side effect of the addition of $\mathrm{Sr}$ was the formation of Sr-containing intermetallic compounds. These intermetallic compounds might be nucleated on a bifilm defect. Miresmaeili ${ }^{[26]}$ calculated the lattice mismatch between $\mathrm{MgAl}_{2} \mathrm{O}_{4}$ spinel and $\mathrm{Al}_{2} \mathrm{Si}_{2} \mathrm{Sr}$ to be 4.26 pct, and suggested that spinel could be a favored nucleation site for the growth of intermetallic compounds.

In this work, two designs of sand mold were used to produce castings with higher and lower amounts of bifilm defects. The interaction between additions of the modifier $\mathrm{Sr}$ and bifilm defects was investigated by comparing the change in mechanical properties of castings from the two sand mold designs.

\section{EXPERIMENTAL PROCEDURE}

Castings with higher bifilm defect contents were achieved by casting the mold design shown in Figure 1. The splashing associated with the liquid metal transfer during mold filling should have introduced many bifilm defects into the liquid metal to produce bifilm-rich castings. Oxide film defects formed earlier, during the metal melting stage or residual from the metal ingot and carried into the casting (termed 'old bifilm defects'), would also contribute to the bifilm defect population in the castings. 8 molds were cast of 2L99 alloy (to give 77 test bars), and 3 molds were cast with $2 \mathrm{~L} 99+300 \mathrm{ppm} \mathrm{Sr}$, to give 30 test bars containing Sr. The molds were made one week prior to casting to allow the evaporation of hydrogen-containing volatiles from the resin binder.

To produce castings with a reduced amount of bifilm defects, the mold design shown in Figure 2 was used. A 20 ppm filter was placed in the cente of the runner bar at the bottom of the downsprue (labeled in Figure 2), which would have the effect of filtering out some of the previously introduced bifilms, and would also reduce the velocity of the liquid metal entering the mold. In these experiments, 3 molds each were cast in 2L99 alloy, and with 2L99 alloy modified by an addition of 300 ppm Sr, giving 30 test bars each.

The liquid metal was poured at $725^{\circ} \mathrm{C}$ (998 K). Before that, Argon gas was bubbled from the bottom of the liquid metal to degas for 20 minutes. For the casting with poor running system design, a cooling stick was subsequently inserted into the downsprue as long as the metal was cast. The molds were then rolled 180 degree. This was to allow the proper feeding of the test bar from the running system. The castings were subject to a T6 heat treatment, consisting of a $540{ }^{\circ} \mathrm{C}(813 \mathrm{~K})$ solution treatment for 12 hours, followed by quenching in hot water at $65^{\circ} \mathrm{C}(338 \mathrm{~K})$ and by precipitation hardening for 3.5 hours at $155^{\circ} \mathrm{C}(428 \mathrm{~K})$.

Table I lists the chemical composition of the alloys used in the casting experiments. The pickup rate of the modifier in the casting was confirmed by measurement of their composition using Inductively Coupled Plasma Mass Spectrometry (ICP-MS). This suggested that the $\mathrm{Sr}$ addition had a full recovery rate, giving a Sr content of $0.03 \mathrm{wt}$ pet in the castings with both high and low bifilm defect content.

The composition of the alloy in the case of other elements that might affect the variability of mechanical properties (i.e., $\mathrm{Mg}$ and $\mathrm{Fe}$ ) was determined using a Tiger S8 WDXRF (see Table II), which suggested that the $\mathrm{Fe}$ and $\mathrm{Mg}$ contents were all controlled within an acceptable range with $\mathrm{Fe}<0.12 \mathrm{wt}$ pct and $\mathrm{Mg}$ $0.3 \pm 0.03$ wt pet.

Hydrogen content analysis by $\mathrm{LECO}^{\mathrm{TM}}$ (shown in Table III) suggested that the castings also had similar hydrogen contents, of about $0.17 \pm 0.03 \mathrm{ppm}$. 
A section of the running system from each casting was cut and polished, to $0.25 \mu \mathrm{m}$, using standard techniques for optical microscopy and examined using a Leica

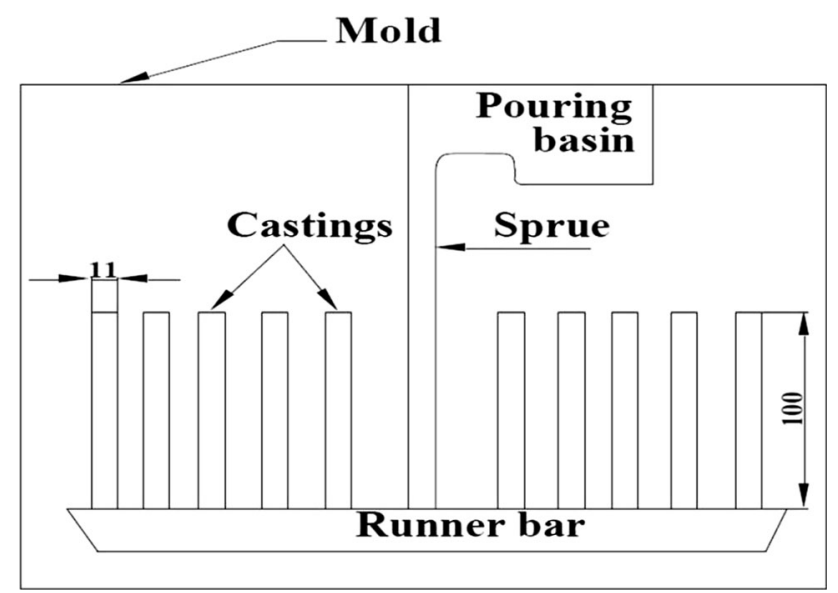

Fig. 1-A diagram showing the running system design of the test bar mold used in the experiments to generate high double oxide film defect content in the test bar castings.
Optical Microscope. Figure 3 shows the morphology of the eutectic Si phase in the castings. Figure 3(a) shows an acicular shaped $\mathrm{Si}$ phase in the unmodified 2L99 alloy but was fully modified into a coral morphology with much smaller size, as shown in Figure 3(b).

The cast test bars were machined to produce a gage length of 37 and $6.75 \mathrm{~mm}$ in diameter. The radius of the shoulder of the gage length was $26 \mathrm{~mm}$. Tensile testing was conducted using a Zwick tensile testing machine at a strain rate of $1 \mathrm{~mm} / \mathrm{min}$, with the UTS and pet Elongation of each test bar recorded. The mechanical properties of the test bars from the unmodified 2L99 castings and modified 2L99 castings were compared for both casting types.

The difference in the amount of bifilm defects was confirmed by examination of the fracture surfaces of 30 test bars (representing 3 molds) from each composition using a Leica X200 camera. The size of the bifilm defect(s) on each fracture surface was measured using ImageJ. The fracture surfaces of the tensile test bars were further observed using a JEOL 7000 Scanning Electron Microscope (SEM), equipped with Oxford INCA EDX.

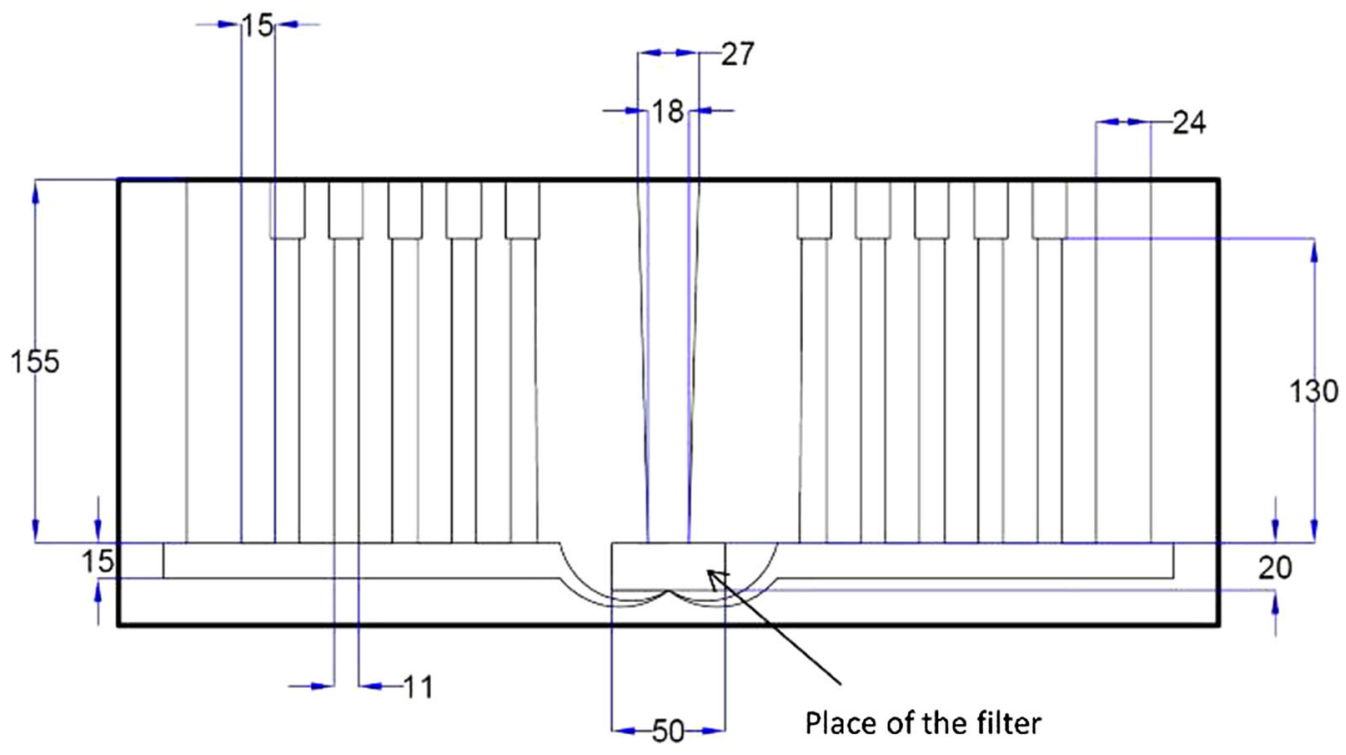

Fig. 2-A diagram showing the running system design of the test bar mold used in the experiments to generate reduced double oxide film defect content in the test bar castings.

Table I. Composition of the 2L99 Alloy Used in the Experiments

\begin{tabular}{lccccccccccccc}
\hline Element & $\mathrm{Si}$ & $\mathrm{Fe}$ & $\mathrm{Cu}$ & $\mathrm{Mn}$ & $\mathrm{Mg}$ & $\mathrm{Cr}$ & $\mathrm{Ni}$ & $\mathrm{Zn}$ & $\mathrm{Pb}$ & $\mathrm{Sn}$ & $\mathrm{Ti}$ & $\mathrm{Al}$ \\
\hline Composition & 7 & 0.1 & 0.01 & 0.01 & 0.34 & 0.01 & 0.01 & 0.01 & 0.01 & 0.01 & 0.1 & bal. \\
\hline
\end{tabular}

Table II. Chemical Composition of the Castings, Measured by XRF

\begin{tabular}{lcccc}
\hline & \multicolumn{2}{c}{ Castings with High Bifilm Content } & \multicolumn{2}{c}{ Castings with Low Bifilm Content } \\
\cline { 2 - 4 } Element & $2 \mathrm{~L} 99+\mathrm{Sr}$ & $2 \mathrm{~L} 99$ & \multicolumn{2}{c}{ 2L99+Sr } \\
\hline Fe (wt pct) & 0.1 & 0.1 & 0.1 & 0.09 \\
$\mathrm{Mg}($ wt pct) & 0.3 & 0.32 & 0.32 & 0.33 \\
\hline
\end{tabular}


The tensile test results for each set of test bars were fitted using a two-parameter Weibull distribution, using linear regression, and the Weibull parameters evaluated to obtain their shape parameter (i.e., the Weibull modulus, showing the scatter of the results) and scale parameter (i.e., the Position Parameter, within which $1-1 / e(63.4 \mathrm{pct})$ of the data might fail). The cumulative distribution function of the two-parameter Weibull distribution used here is given by Eq. [1]:

$$
P=1-e^{-\left(\frac{x}{x_{0}}\right)^{m}},
$$

where $P$ is the probability of failure, $x$ the measured data point (e.g., UTS, pct Elongation, etc.), $x_{0}$ the position parameter, and $m$ is the Weibull modulus.

The probability of failure of the samples was unknown and was obtained using the estimation equation as follows ${ }^{[27]}$ :

$$
P=\frac{n_{i}-0.5}{n+0.25}
$$

where $P$ is the probability of sample failure, $n_{i}$ the sample rank, and $n$ is the total sample size.

\section{RESULTS}

\section{A. Statistical Analysis of the Weibull Moduli}

Weibull plots for high and low bifilm defect-containing castings are shown in Figure 4 . In this work, $R^{2}$ was used to assess the goodness of fit of the Weibull distribution for a data set. The tensile test results from the casting can only be accepted as following a Weibull distribution if $R^{2}>R_{0.05}^{2} \cdot R_{0.05}^{2}$ has been shown in

Table III. Hydrogen Analysis Results, Measured by $\mathrm{LECO}^{\mathrm{TM}}$

\begin{tabular}{lcc}
\hline & $\begin{array}{c}\text { High Bifilm } \\
\text { Content }(\mathrm{ppm})\end{array}$ & $\begin{array}{c}\text { Low Bifilm } \\
\text { Content }(\mathrm{ppm})\end{array}$ \\
\hline 2L99 $+\mathrm{Sr}$ & 0.182 & 0.138 \\
2L99 & 0.197 & 0.192 \\
\hline
\end{tabular}

Eq. [3], suggested by Tiryakioğlu et al. ${ }^{[28]}$ with sample size n: 1 to 100 and 95 pct confidence. $R_{0.05}^{2}$ and $R^{2}$ values for various castings are shown in Table IV. A summary of the tensile test results is provided in Tables V and VI.

$$
R_{0.05}^{2}=1.0637-\frac{0.4174}{n^{0.3}}
$$

If the data set was accepted as having a Weibull distribution, a statistical method was used to compare the difference of Weibull moduli (shape parameter) between modified castings and unmodified castings with
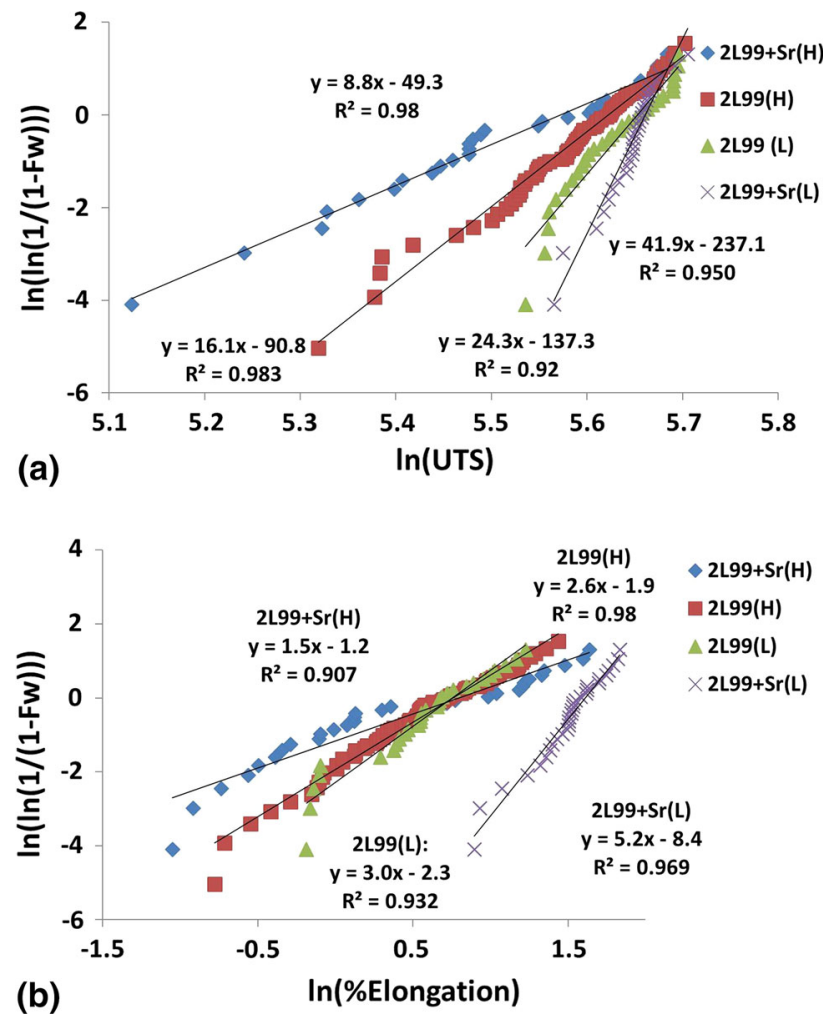

Fig. 4- Graphs of the Weibull plots for (a) UTS and (b) pct Elongation for 2L99 castings, with and without $\mathrm{Sr}$ modification, in castings containing both high $(\mathrm{H})$ and Low (L) bifilm defect content.

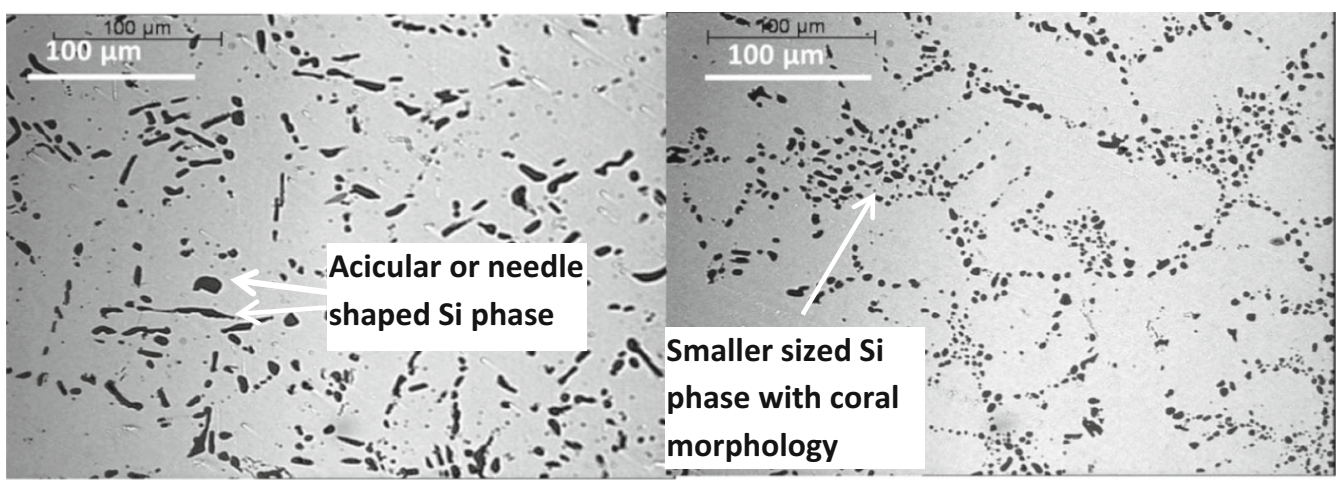

(a) (b)

Fig. 3-Morphology of the Si phase in (a) 2L99 alloy and (b) 2L99 castings modified with Sr. 
Table IV. A Table of $\boldsymbol{R}^{2}$ Values Showing the Goodness of Fit for the Data from the Different Castings

\begin{tabular}{|c|c|c|c|c|}
\hline & \multicolumn{2}{|c|}{ Casting with High Bifilm Content } & \multicolumn{2}{|c|}{ Casting with Low Bifilm Content } \\
\hline & $2 \mathrm{~L} 99+\mathrm{Sr}$ & 2L99 & $2 \mathrm{~L} 99+\mathrm{Sr}$ & 2L99 \\
\hline Sample size & 30 & 77 & 30 & 30 \\
\hline$R_{0.05}^{2}$ & 0.91 & 0.95 & 0.91 & 0.91 \\
\hline$R^{2}$ value for UTS & 0.9811 & 0.9837 & 0.9494 & 0.9305 \\
\hline Accepted as Weibull distribution & yes & yes & yes & yes \\
\hline$R^{2}$ Value for pct Elongation & 90.65 pct & $96.14 \mathrm{pct}$ & $95.66 \mathrm{pct}$ & $93.24 \mathrm{pct}$ \\
\hline Accepted as Weibull distribution & no & yes & yes & yes \\
\hline
\end{tabular}

Table V. Summary of the Ultimate Tensile Strength Values from the Tensile Test Results

\begin{tabular}{|c|c|c|c|c|}
\hline & \multicolumn{2}{|c|}{ High Bifilm Defect Content $(\mathrm{H})$} & \multicolumn{2}{|c|}{ Low Bifilm Defect Content (L) } \\
\hline & $2 \mathrm{~L} 99+\mathrm{Sr}$ & 2L99 & $2 \mathrm{~L} 99+\mathrm{Sr}$ & 2L99 \\
\hline Mean (MPa) & 248.41 & 270 & 283.6 & 278.07 \\
\hline Position parameter $(\mathrm{MPa})$ & 262.99 & 277 & 287.5 & 284.88 \\
\hline Standard deviation & 32.29 & 15.3 & 8.1 & 14.3 \\
\hline Weibull moduli & 8.86 & 16.15 & 41.9 & 23 \\
\hline
\end{tabular}

Table VI. Summary of the Percent Elongation Values from the Tensile Test Results

\begin{tabular}{|c|c|c|c|c|}
\hline & \multicolumn{2}{|c|}{$\begin{array}{l}\text { High Bifilm Defect Content } \\
(\mathrm{H})\end{array}$} & \multicolumn{2}{|c|}{ Low Bifilm Defect Content (L) } \\
\hline & $2 \mathrm{~L} 99+\mathrm{Sr}$ & 2L99 & $2 \mathrm{~L} 99+\mathrm{Sr}$ & 2L99 \\
\hline Mean (pct Elongation) & 2 & 1.9 & 4.59 & 1.88 \\
\hline Position parameter (pct Elongation) & $\mathrm{N} / \mathrm{A}$ & 2.13 & 5 & 2.13 \\
\hline Standard deviation & 1.47 & 0.86 & 0.97 & 0.7 \\
\hline Weibull moduli & $\mathrm{N} / \mathrm{A}$ & 3.01 & 5.24 & 3.02 \\
\hline
\end{tabular}

Table VII. Statistical Analysis of the Weibull Moduli of the 2L99 Alloy and Sr-Modified 2L99 Alloy Castings

\begin{tabular}{lcc}
\hline & High Bifilm Defect Content $(\mathrm{H})$ & \multicolumn{2}{c}{ Low Bifilm Defect Content (L) } \\
2L99, 2L99+Sr & 30,30 \\
\hline Sample size $\left(n_{1}, n_{2} ; n_{1}>n_{2}\right)$ & 77,30 & $0.596,1.677$ \\
2.5 and 97.5 percentiles & $0.67,1.502$ & 0.58 \\
$m_{1} / m_{2}$ value (UTS) & 1.82 & yes \\
Statistical difference & yes & 0.58 \\
$m_{1} / m_{2}$ value (pct Elongation) & N/A & yes \\
Statistical difference & N/A & \\
\hline
\end{tabular}

the help of a simulation. ${ }^{[29]}$ Two data sets, with sample size $\mathrm{n}_{1}$ and $n_{2}$ (where $n_{1}>n_{2}$ ), respectively, were generated with a Monte-Carlo method which followed a Weibull distribution with shape parameter $m=1$ and scale parameter $\sigma_{0}=3$. The Weibull moduli of the two data sets were evaluated using a linear regression method which gave Weibull moduli of $m_{1}$ and $m_{2}$. The value of $\mathrm{m}_{1} / \mathrm{m}_{2}$ was recorded and this process was repeated 100,000 times until a clear distribution was obtained. From this distribution, 2.5 and 97.5 percentiles were obtained.

The ratio of the Weibull moduli of the UTS and the pct Elongation of the 2L99 alloy castings, with and without $\mathrm{Sr}$ modifier additions, was determined and, if this value fell between the 2.5 and 97.5 percentiles, then the Weibull moduli of the two castings was assumed to be similar, but if the ratio fell outside the 2.5 and 97.5 percentiles, a statistically significant difference between the two Weibull moduli existed. The corresponding 2.5 and 97.5 percentiles for the different sample sizes used in this work are shown in Table VII.

For the castings with high bifilm defects, this statistical analysis suggested that (see Figure 4, summarized in Tables IV through VII) the Weibull moduli of the UTS showed a statistically significant decrease, from 16.2 to 8.9 , when $\mathrm{Sr}$ was added into the casting. The $R^{2}$ value for the Weibull plot of the pct Elongation was too low for it to be accepted as a Weibull plot. Instead, the Weibull plot showed the presence of two distributions of data, which could be caused by different types of defects accounting for the failure of the samples, perhaps porosity as well as bifilm defects. 


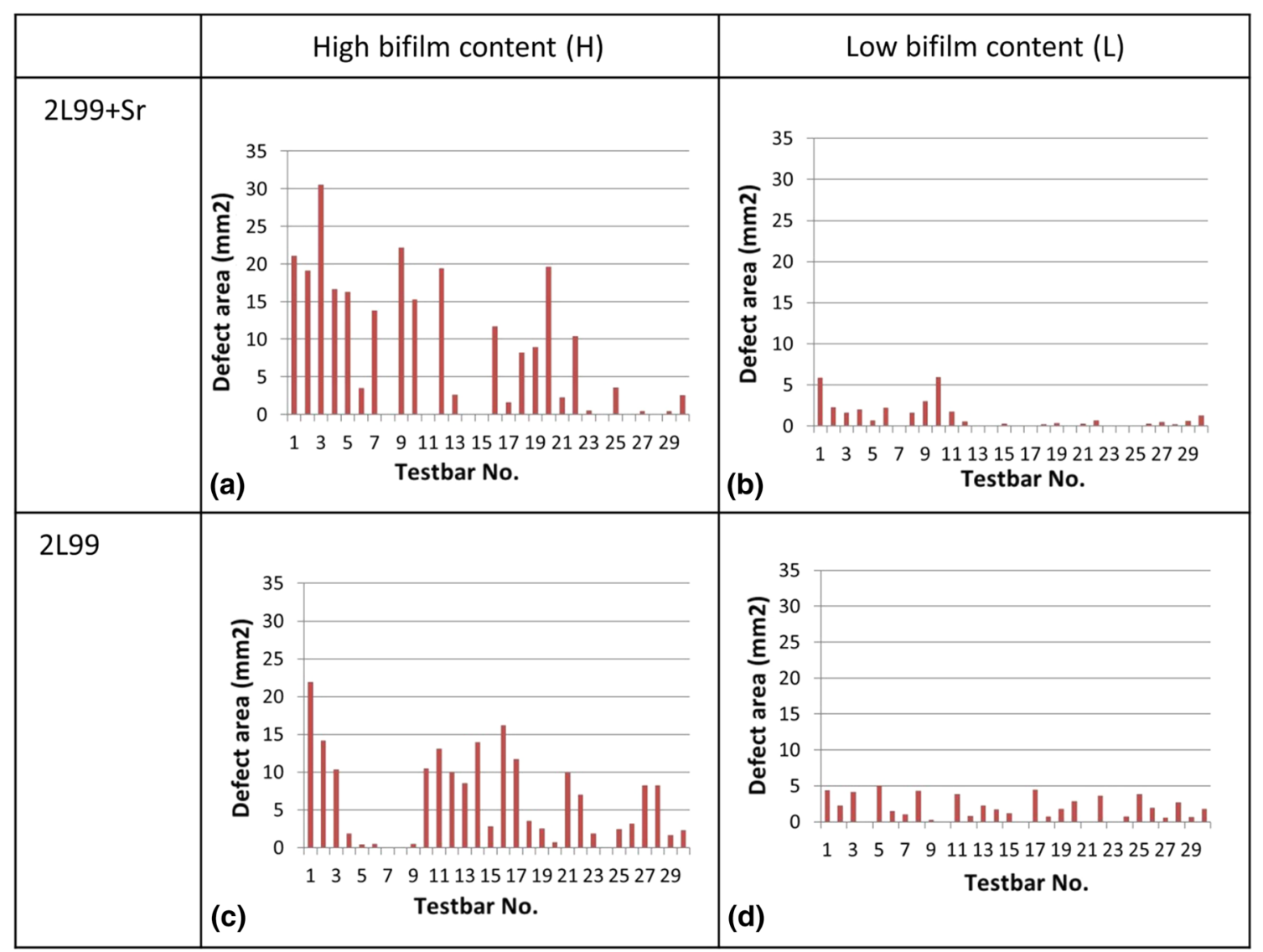

Fig. 5-Histograms showing the measured areas of bifilm defect on the fracture surfaces of $(a)$ Sr-modified 2 L99 castings with bifilm defect content $(\mathrm{H}),(b)$ Sr-modified 2L99 castings with low oxide film defect content (L), (c) 2L99 casting with high oxide film defect content (H), and (d) 2L99 casting with low oxide film defect content (L).

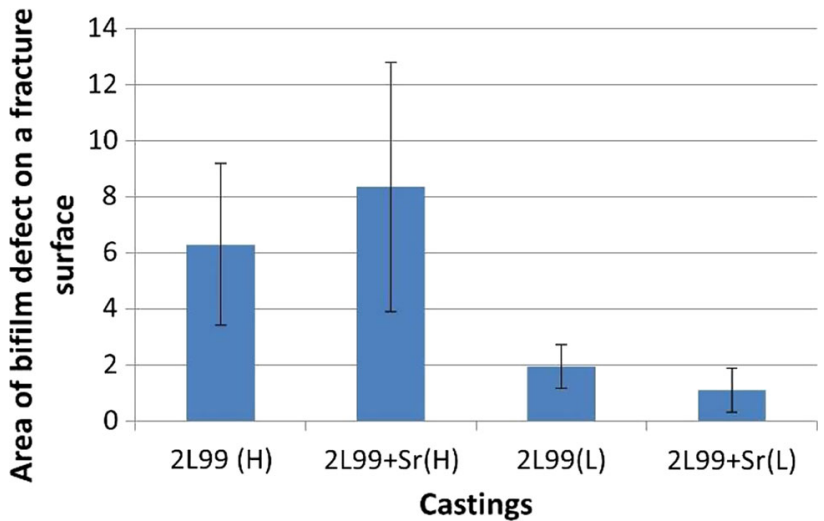

Fig. 6- Histograms showing the mean value of the bifilm defect measured on the fracture surface of the castings shown in Fig. 5.

When the bifilm content in the casting was lower (i.e., the castings with the better mold design shown in Figure 2), the addition of Sr tended to have a strong positive effect on mechanical properties. The Weibull plots are shown in Figure 4, and the results are summarized in Tables IV through VII, showing that the addition of Sr shifted the Weibull moduli of the UTS from 24 to 42 . The corresponding value for the pct Elongation was increased from 3.0 to 5.2. Analysis suggested that both improvements were statistically significant.

\section{B. Quantification of Bifilm Defect Size on the Fracture Surfaces}

A histogram of the areas of the bifilm defects in the castings is shown in Figure 5. For castings with high bifilm defect content (no modification, Figure 5(c)), the mean bifilm defect size on the fracture surface was about 6 pct of the total cross-sectional area of the samples. This number decreased to about 2 pct in the castings with low bifilm defect content (no modification, Figure 5(d)). A similar trend was seen in the Sr-modified castings. The mean bifilm defect size on the fracture surface decreased from about 8 pct to about 1 pct when the bifilm defect content in the casting was reduced. This confirmed that the use of two different mold designs had resulted in different bifilm defect contents in the castings. The comparisons of the mean value of the size of the bifilm defects on the fracture surfaces in the various castings are shown in Figure 6.

\section{Fracture Surface Analysis of the Cast Test bars}

Figures 7 and 8 show examples of fracture surfaces of 2L99 and 2L99 + Sr alloy test bars, with both high and low bifilm defect contents, respectively. For the castings 


\begin{tabular}{|c|c|c|c|}
\hline Castings & $\begin{array}{l}\text { With good mechanical } \\
\text { properties }\end{array}$ & $\begin{array}{l}\text { With average mechanical } \\
\text { properties }\end{array}$ & $\begin{array}{l}\text { With bad mechanical } \\
\text { properties }\end{array}$ \\
\hline \multicolumn{4}{|l|}{$2 \mathrm{~L} 99+\mathrm{Sr}(\mathrm{H})$} \\
\hline $\begin{array}{l}\text { Main defect in the } \\
\text { casting }\end{array}$ & $\begin{array}{l}\text { porosity ( } 294 \mathrm{MPa}, 4.94 \% \\
\text { Elongation) }\end{array}$ & $\begin{array}{l}\text { oxide film defect ( } 243 \mathrm{MPa} \text {, } \\
1.35 \% \text { Elongation) }\end{array}$ & $\begin{array}{l}\text { oxide film defect(189 } \mathrm{MPa} \\
0.4 \% \text { Elongation ) }\end{array}$ \\
\hline \multicolumn{4}{|l|}{ 2L99(H) } \\
\hline $\begin{array}{l}\text { Main defect in the } \\
\text { casting }\end{array}$ & $\begin{array}{l}\text { oxide film defect (284 MPa, } \\
2.86 \%)\end{array}$ & $\begin{array}{l}\text { oxide film defect ( } 269 \mathrm{MPa} \text {, } \\
1.78 \% \text { Elongation) }\end{array}$ & $\begin{array}{l}\text { oxide film defect ( } 218 \mathrm{MPa} \\
0.50 \% \text { Elongation) }\end{array}$ \\
\hline
\end{tabular}

Fig. 7-Optical microscopy images showing examples of the fracture surfaces of unmodified and Sr-modified 2L99 alloy castings, with high numbers of bifilm defects.

with high bifilm content (Figure 7), a bifilm defect was the main reason for failure in all three representative images (good, average, and poor mechanical properties) for $2 \mathrm{~L} 99$ alloy $(2 \mathrm{~L} 99(\mathrm{H}))$. With $\mathrm{Sr}$ addition $(2 \mathrm{~L} 99+\mathrm{Sr}(\mathrm{H}))$, however, large sized bifilms occurred only on fracture surfaces with poor and average mechanical properties. For the test bar with good mechanical properties, porosity contributed to the failure of the test bars.

For the castings with low bifilm defect content, smaller bifilm defects were observed, with porosity on almost all of the fracture surfaces of the $2 \mathrm{~L} 99+\mathrm{Sr}$ tensile test bars.

SEM and EDX analyses showed two types of defects on test bar fracture surfaces from modified castings, oxide film defects and porosity (shown in Figure 9). This might also explain the tendency for the bimodal distribution of the mechanical properties of $2 \mathrm{~L} 99+\mathrm{Sr}$ castings (shown in Figure 4, having high bifilm defect content). A Sr peak was not detected on the bifilm defect by EDX, which suggested that $\mathrm{Sr}$ might not have altered the oxides, or had a very weak effect on the oxide formation process

Figure 10 shows a polished surface from a 2L99 alloy casting, modified with $\mathrm{Sr}$, containing a high quantity of bifilm defects. EDX analysis at site $\mathrm{X} 1$ showed an oxygen peak, which suggested the presence of a double oxide film defect. Bright-contrast particles were seen on the sides of the bifilm defects, and EDX analysis (site $\mathrm{X} 2$ ) suggested that they might be Sr-containing intermetallic compounds. Table VIII shows a few composition analyses of the Sr-containing intermetallic compound, which suggested the composition of $\mathrm{Al}_{2} \mathrm{Si}_{2} \mathrm{Sr}$.

\section{DISCUSSION}

The lowest Weibull Modulus for the UTS $(m=9)$ was associated with the high-bifilm content castings, to which had been added $300 \mathrm{ppm}$ of $\mathrm{Sr}$ (see Figure 4). A slightly higher Weibull modulus of $m=16$ was obtained when no Sr was added, with the same casting design. This suggests that in castings with poorly designed running systems, and hence high bifilm contents, a $\mathrm{Sr}$ modification treatment might be detrimental and lead to an increase in the scatter in mechanical properties. A slight reduction in mechanical properties of about 5 pct, with a $\mathrm{Sr}$ addition (judged by the Position Parameter), was also suggested (see Table V). 


\begin{tabular}{|c|c|c|c|}
\hline Castings & $\begin{array}{l}\text { With good mechanical } \\
\text { properties }\end{array}$ & $\begin{array}{c}\text { With average mechanical } \\
\text { properties }\end{array}$ & $\begin{array}{c}\text { With bad mechanical } \\
\text { properties }\end{array}$ \\
\hline $2 \mathrm{~L} 99+\operatorname{Sr}(\mathrm{L})$ & & 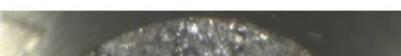 & \\
\hline $\begin{array}{l}\text { Main defect in the } \\
\text { casting }\end{array}$ & (291 MPa,6.0\% Elongation ) & $\begin{array}{c}\text { Porosity( } 273 \mathrm{MPa}, 4.0 \% \\
\text { Elongation) }\end{array}$ & $\begin{array}{c}\text { Bifilm defect/porosity(261 } \\
\mathrm{MPa}, 2.45 \% \text { Elongation) }\end{array}$ \\
\hline 2L99(L) & & & \\
\hline $\begin{array}{l}\text { Main defect in the } \\
\text { casting }\end{array}$ & (289 MPa, 2.6\% Elongation) & $\begin{array}{l}\text { Bi-film defect( } 275 \mathrm{MPa} \text {, } \\
\text { 1.93\%Elongation ) }\end{array}$ & $\begin{array}{l}\text { Bi-film defect ( } 254 \mathrm{MPa} \text {, } \\
0.91 \% \text { Elognation) }\end{array}$ \\
\hline
\end{tabular}

Fig. 8-Optical microscopy images showing examples of the fracture surfaces of unmodified and Sr-modified 2L99 alloy castings, with low numbers of bifilm defects.

Table VIII. Composition of the Sr-Containing Intermetallic Compound, Measured by EDX

\begin{tabular}{|c|c|c|c|c|}
\hline & \multicolumn{4}{|c|}{ At. Pct } \\
\hline & No.1 & No. 2 & No.3 & No.4 \\
\hline $\mathrm{Al}$ & 42 & 41 & 45 & 45 \\
\hline $\mathrm{Si}$ & 39 & 40 & 37 & 37 \\
\hline $\mathrm{Sr}$ & 19 & 19 & 18 & 18 \\
\hline
\end{tabular}

The decrease in Weibull modulus of the UTS can be attributed to the addition of $\mathrm{Sr}$, although several mechanisms by which this effect occurs are possible, with several mechanisms occurring simultaneously also possible. (i) The addition of Sr may have resulted in an increase in the bifilm content, since the $\mathrm{Sr}$ addition was made using an Al-Sr master alloy stirred into the melt, which may have therefore introduced more double oxide film defects into the liquid alloy. Although the similarity in area of defects on the fracture surfaces suggests that this might not be a great effect (see Figure 5), there does appear to be more variability in the defect areas on the fracture surfaces of castings with $\mathrm{Sr}$ modification (compare Figures 5(a) and 5(c)). The highest bifilm defect content observed on a single test bar (associated with the lowest UTS) constituted about 80 pct of the fracture surface for the $\mathrm{Sr}$ addition casting, compared with about 60 pet for the Sr-free castings. In addition, 9 test bars were seen to contain a bifilm defect content higher than 40 pct of the fracture surface in the Sr-containing casting, compared with only 2 test bars in the Sr-free castings. The larger oxide film defects in the Sr-modified casting might be associated with poorer mechanical properties which contributed to a low Weibull modulus (as the Weibull modulus was quite tail sensitive). (ii) The addition of $\mathrm{Sr}$ should have altered the eutectic Si morphology (see Figure 3). An improvement in fineness of the eutectic $\mathrm{Si}$ particles would 


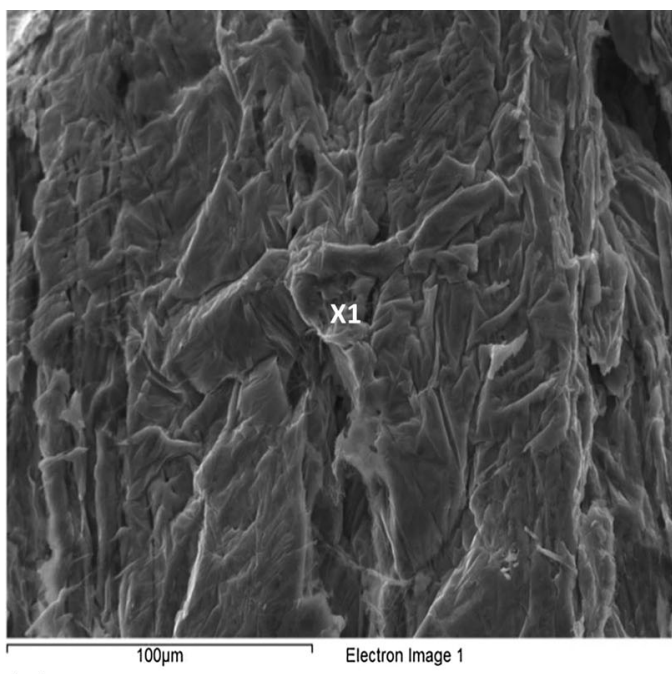

(a)

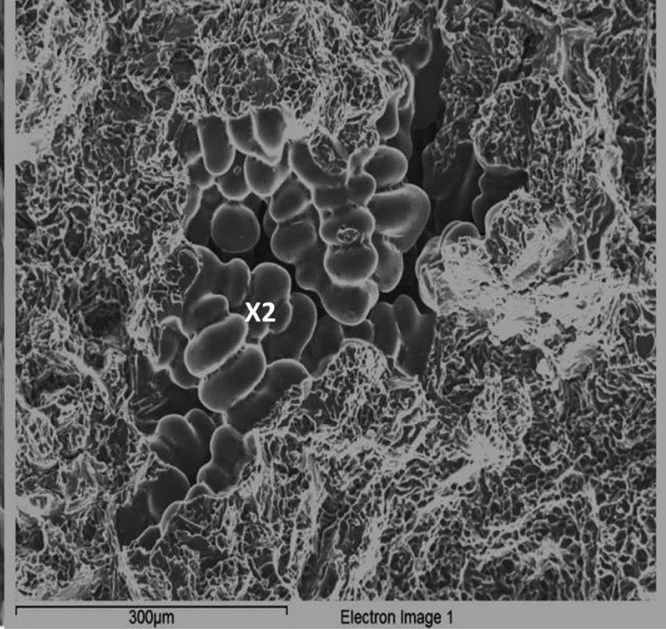

(b)
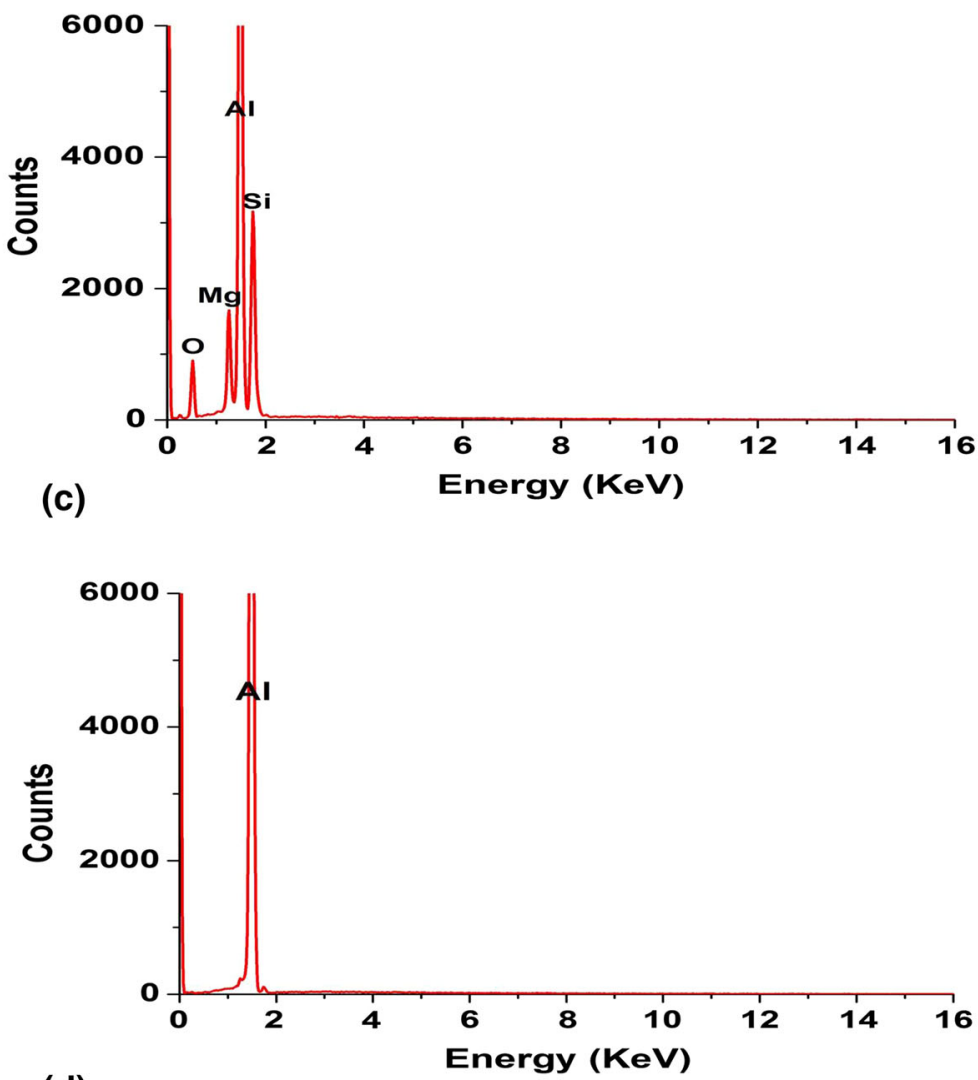

(d)

Fig. 9-SEM micrographs showing $(a)$ an oxide film defect and $(b)$ porosity, found on the fracture surfaces of 2L99 castings modified with Sr; $(c)$ and $(d)$ The associated EDX spectra obtained from the points labeled X1 and X2 (Sr peak should occur at 14.1 KeV).

improve the mechanical properties and reduce the variation in mechanical properties (but by an amount difficult to deduce). However, no increase in UTS was noted in comparing these results, although pct Elongation was increased by about 3 pct with the $\mathrm{Sr}$ addition (see Table VII). This could be because the detrimental effect of high bifilm defects introduced into the casting played a more important role in determining the mechanical properties compared with the beneficial effect from the effect of modification. (iii) Earlier work has suggested a redistribution of solidification shrinkage from macroshrinkage to microshrinkage, ${ }^{[30]}$ which might alter the shrinkage formation position and result in the formation of some of the shrinkage porosities in the test bar (which the original mold designed were to avoid). This may be a contributing factor to the decrease 


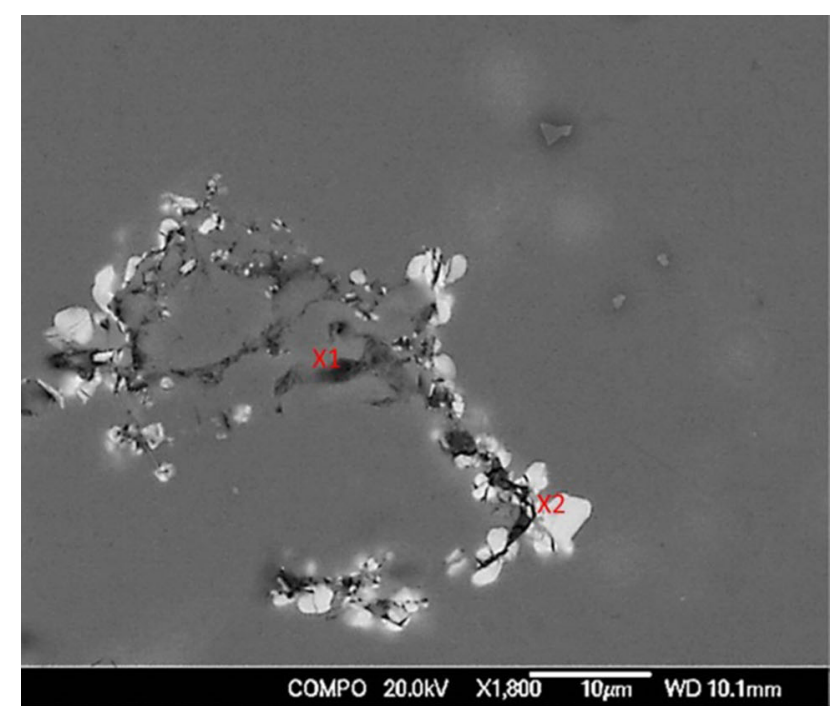

(a)
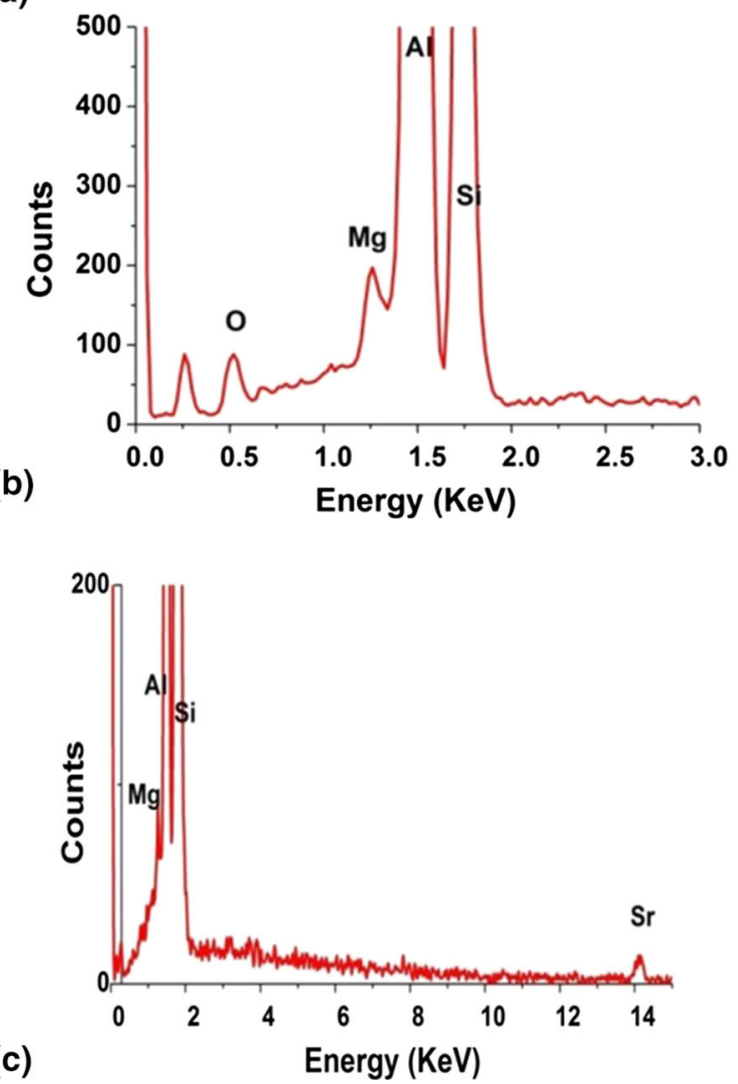

Fig. 10-(a) An example of a SEM micrograph of a polished cross-section surface of a Sr-modified 2L99 alloy, from a high-bifilm content casting, showing Sr-containing intermetallic compound growing on the sides of a double oxide film defect; $(b)$ and $(c)$ with the associated EDX spectrum at the points labeled X1 and X2 respectively.

in Weibull Modulus associated with Sr. (iv) Figure 10 shows intermetallic compounds (possibly $\mathrm{Al}_{2} \mathrm{Si}_{2} \mathrm{Sr}$ ) presumed to have been nucleated on a bifilm defect, where many particles are seen growing away from the defect. The presence of the Sr-containing intermetallic particles may have enhanced the detrimental effect of $\mathrm{Sr}$ on the alloy, perhaps by acting as a conduit for $\mathrm{H}$ to diffuse into the interior atmosphere of bifilms, allowing them to expand, or by virtue of their nucleation relationship with the bifilm, making it act as a more severe defect.

No statistically significant difference was noted in the pct Elongation results (see Table VII), although in the case of the high-bifilm content castings with $\mathrm{Sr}$ the results showed tendency for a bimodal distribution (reflecting two different causes of failure, bifilm defects and porosity).

However, the use of a well-designed running system produced an opposite effect. The highest Weibull Modulus for the UTS $(m=42)$ was associated with low-bifilm content castings to which had been added 300 ppm Sr (see Figure 4). A significantly lower Weibull modulus of $m=24$ was obtained with the same casting design (and hence presumably similar bifilm content) with no $\mathrm{Sr}$ addition. (This was also shown in the similarity in the measured area of the bifilms, determined from the fracture surfaces, of 1 and $2 \mathrm{pct}$, respectively (see Figure 6).)

Figures 7 and 8 show examples of fracture surfaces from the different casting experiments. Oxide film defects were found on fracture surfaces with a low bifilm content, when $m=24$, but porosity was more frequently observed with low bifilm content castings with $\mathrm{Sr}$ added. The high Weibull modulus of 42 is probably attributed to the low bifilm defect content and the transition to a more reproducible size of defect causing failure, namely porosity, which would be more spherical, compared to a two-dimensional type of defect such as a bifilm. The beneficial effect on the mechanical properties by the Si phase modification outweighed the detrimental effect from the casting defects (i.e., bifilm defect and porosity).

No evidence was found for the addition of $\mathrm{Sr}$ causing a change in the composition or structure of the bifilm defects. Previous explanations of the role of bifilm defects in affecting mechanical properties have focussed on the reaction of the interior gases with the surrounding melt, reducing their size and reducing their impact on properties. ${ }^{[18,23,31]}$ In these experiments, it has been shown that the use of a good running system design, coupled with a transition to spherical porosity, has resulted in the most reproducible mechanical properties.

\section{CONCLUSIONS}

1. Tensile test results suggested that the addition of $300 \mathrm{ppm} \mathrm{Sr}$ in a high bifilm defect-containing 2L99 alloy tended to have a negative effect on mechanical properties of the castings, reducing the Weibull modulus of the UTS and increasing its variability.

2. When the running system design was changed and the bifilm defect content in the casting was reduced, a significant improvement in the Weibull modulus of the UTS and pct Elongation was seen. The mean value of pet Elongation was also improved by 300 pet. 
3. The increased bifilm defect content, increased amount of porosity, and the effect of intermetallic compounds nucleating on the sides of the bifilm defect could all be reasons why an addition of $\mathrm{Sr}$ reduced the Weibull moduli of the UTS in a high bifilm-containing 2L99 casting.

4. For castings with a low bifilm defect content, the beneficial effect of the $\mathrm{Sr}$ addition was probably due to the effect of Si modification (which outweighed the detrimental effect of double oxide film defects, due to the reduced defect content in the casting).

\section{ACKNOWLEDGMENTS}

The authors would like to acknowledge the EPSRC Center-LiME for providing partial financial support under Grant EP/H026177/1. The technical assistance of $\mathrm{Mr}$. A. Caden at the University of Birmingham is also gratefully acknowledged.

\section{OPEN ACCESS}

This article is distributed under the terms of the Creative Commons Attribution 4.0 International License (http://creativecommons.org/licenses/by/4.0/), which permits unrestricted use, distribution, and reproduction in any medium, provided you give appropriate credit to the original author(s) and the source, provide a link to the Creative Commons license, and indicate if changes were made.

\section{REFERENCES}

1. D. Emadi, J.E. Gruzleski, and J.M. Toguri: Metall. Trans. B, 1993, vol. 24 (6), pp. 1055-63.

2. J.E. Gruzleski and B.M. Closset: AFS Trans., 1990, vol. 92, p. 256.

3. S.C. Flood and J.D. Hunt: Met. Sci., 1981, vol. 15 (7), pp. 287-94.

4. A. Knuutinen, K. Nogita, S.D. McDonald, and A.K. Dahle: Light Met., 2001, vol. 1 (4), pp. 229-40.
5. K. Nogita, S.D. McDonald, and A.K. Dahle: Mater. Trans., 2004, vol. 45 (2), pp. 323-26.

6. G. Sigworth: AFS Trans., 1983, vol. 66, pp. 7-16.

7. S.D. McDonald, K. Nogita, and A.K. Dahle: Acta Mater., 2004, vol. 52 (14), pp. 4273-80.

8. N.S. Tiedje, J.A. Tayor, and M.A. Easton: Metall. Trans. A, 2012, vol. 43 (12), pp. 4846-58.

9. S.Z. Lu and A. Hellawell: Metall. Trans. A, 1987, vol. 18 (10), pp. 1721-33.

10. D.R. Hamilton and R.G. Seidensticker: J. Appl. Phys., 1960, vol. 31, pp. 1165-73.

11. J. Li, F. Hage, M. Wiessner, L. Romaner, D. Scheiber, B. Sartory, Q. Ramasse, and P. Schumacher: Sci. Rep., 2015, vol. 5, p. 13802.

12. M. Timpel, N. Wanderka, R. Schlesiger, T. Yamamoto, N. Lazarev, D. Isheim, G. Schmitz, S. Matsumura, and J. Banhart: Acta Mater., 2012, vol. 60, pp. 3920-28.

13. H. Eiken and M. Apel: IOP Conf. Ser. Mater. Sci. Eng., 2016, vol. 84 (1), p. 12084.

14. J. Campbell: Complete Casting Handbook, Butterworth-Heinemann, Oxford, 2011, pp. 19-28.

15. W. Weibull: J. Appl. Mech. Tran. ASME, 1951, vol. 18 (3), pp. 293-97.

16. N.R. Green and J. Campbell: J. Mater. Sci. Eng. A, 1993, vol. 173 (1), pp. 261-66.

17. M. Tiryakioğlu and D. Hudak: J. Mater. Sci., 2008, vol. 527 (1-2), pp. 397-99.

18. C. Nyahumwa, N.R. Green, and J. Campbell: AFS Trans., 1998, vol. 106, pp. 215-23.

19. H. Iwahori, K. Yonekura, Y. Yamamoto, and M. Nakamura: $J$. Jpn. Foundrym. Soc., 1989, vol. 61 (10), pp. 730-35.

20. D. Emadi, J. Gruzleski, and M. Pekguleryuz: AFS Trans., 1996, vol. 104 , pp. $763-68$.

21. S. Jacob: Fonderie, 1977, vol. 363, pp. 13-25.

22. J. Campbell and M. Tiryakioglu: J. Mater. Sci. Technol., 2010, vol. 26 (3), pp. 262-68.

23. R. Raiszadeh and W.D. Griffiths: Metall. Trans. B, 2006, vol. 37 (6), pp. 865-71.

24. M. Nateghian, R. Raiszadeh, and H. Doostmohammadi: Metall. Trans. B, 2012, vol. 43 (6), pp. 1540-49.

25. B. Farhoodi, R. Raiszadeh, and M.H. Ghanaatian: J. Mater. Sci. Technol., 2014, vol. 30 (2), pp. 154-62.

26. S.M. Miresmaeili, J. Campbell, S.G. Shabestari, and S.M.A. Boutorabi: Metall. Trans. A, 2005, vol. 36 (9), pp. 2341-49.

27. A. Khalili and K. Kromp: J. Mater. Sci., 1991, vol. 26 (24), pp. $6741-52$.

28. M. Tiryakioğlu and J. Campbell: Metall. Trans. A, 2010, vol. 41 (12), pp. 3121-29.

29. D. Hudak and M. Tiryakioğlu: Mater. Sci. Eng. A, 2011, vol. 528 (27), pp. 8028-30.

30. G.K. Sigworth: Int. J. Metalcast., 2008, vol. 2 (2), pp. 19-40.

31. M.A. El-Sayed, A.G. Salem, A.Y. Kandeil, and W.D. Griffiths: Metall. Trans. B, 2014, vol. 45 (4), pp. 1398-1406. 